Hydraulic Engineering Repository

Ein Service der Bundesanstalt für Wasserbau

Li, Hua; Barkdoll, Brian D.; Kuhnle, Roger Parallel Walls As An Abutment Scour Countermeasure

Verfügbar unter / Available at:

https://hdl.handle.net/20.500.11970/99880

Vorgeschlagene Zitierweise / Suggested citation:

Li, Hua; Barkdoll, Brian D.; Kuhnle, Roger (2004): Parallel Walls As An Abutment Scour Countermeasure. In: Chiew, Yee-Meng; Lim, Siow-Yong; Cheng, Nian-Sheng (Hg.): Proceedings 2nd International Conference on Scour and Erosion (ICSE-2). November 14.-17., 2004, Singapore. Singapore: Nanyang Technological University. 


\title{
PARALLEL WALLS AS AN ABUTMENT SCOUR COUNTERMEASURE
}

\author{
HUA LI \\ ${ }^{1}$ Michigan Tech University, Civil and Environmental Engineering Dept., \\ Houghton, MI 49931 USA, huli@mtu.edu \\ BRIAN D. BARKDOLL \\ ${ }^{1}$ Michigan Tech University, Civil and Environmental Engineering Dept., \\ Houghton, MI 49931 USA, barkdoll@mtu.edu \\ ROGER KUHNLE \\ USDA-ARS National Sedimentation Laboratory, P.O. Box 1157, \\ Oxford, MS 38655, rkuhnle@msa-oxford.ars.usda.gov
}

\begin{abstract}
Scour at bridge abutments can cause damage or failure of bridges and result in excessive repairs, loss of accessibility, or even death. To mitigate abutment scour, clear-water laboratory experiments in a compound channel with an erodible main-channel bad and rigid floodplain were performed using parallel walls. These experiments will aid in developing design guidelines for scour countermeasures for well vegetated or rigid banks and floodplain. Two types of parallel walls were tested: the first was made of a solid thin wood plate and the second was made of piled rocks. For solid parallel walls, a series of rectangular straight plates of different length attached to the upstream end of a wing wall abutment parallel to the flow direction were employed. The velocity was $90 \%$ of its incipient motion value for bed sediment movement. The bed material was sand with a mean diameter of $0.8 \mathrm{~mm}$. All the plates were seated at the bottom of the bank slope and were even with the abutment face parallel to the flume wall. It was found that straight plates thus situated are able to move the scour hole from the upstream abutment corner and are efficient as a countermeasure to prevent scour there. As the length of the plate increased, the scour at the abutment declined and as the plate reached $1.1 \mathrm{~L}$, where $\mathrm{L}$ is the length of the abutment perpendicular to the flow, the scour depth at the abutment was minimum. It was also found that a triangular-shaped or submerged end could reduce the scour at the upstream end of the plate. For parallel rock walls, various values of wall length and protrusion length into the main channel were tested. It was found that a wall that does not protrude into the main channel with a length of $0.5 \mathrm{~L}$ length minimizes scour at the abutment where $\mathrm{L}$ is the length of the abutment perpendicular to the flow.
\end{abstract}

\section{Introduction}

Scour at bridge abutments can cause damage or failure of bridges and result in excessive repairs, loss of accessibility, or even death. There are many countermeasures that have been proposed, but parallel walls are singled out in this paper as being a new and attractive alternative. Previous work on the related topic of guidebanks includes Spring (1903), Lagasse et al. (1999, 2001), and Richardson and Simons (1984).

This study focuses on abutments on a rigid floodplain and banks whose face is even with the toe of the main channel. This situation is common in well-vegetated, smaller stream with older abutments. While typical guidebanks have an ellipcital upstream end, a parallel wall does not and, therefore, would be less expensive due to the difficulty of construction of the elliptical shape. The efficacy of parallel walls without the elliptical end, was, therefore, tested here.

\section{Experimental Procedure and Results}

All of the experiments were conducted in a flume located in the hydraulic laboratory at the National Sedimentation Laboratory, Oxford, MS. The flume channel was $30 \mathrm{~m}$ long, $1.2 \mathrm{~m}$ wide, and $0.6 \mathrm{~m}$ deep, and it was supported in the center at two points and on the ends by four screw jacks that allow the channel slope to be adjusted. The model abutment was located over a $3 \mathrm{~m}$ long, $1.2 \mathrm{~m}$ wide, by $1.2 \mathrm{~m}$ deep recessed section of the flume $22 \mathrm{~m}$ downstream from the inlet tank.

The channel section of the experiments is illustrated in Figure 1. It was a compound channel consisting of an asymmetric floodplain of width $320 \mathrm{~mm}$ next to a main channel that has a bank slope of 1:1 (H:V). The height between the top of the floodplain and the main channel bed, $\mathrm{y}_{\mathrm{m}}$, was $80 \mathrm{~mm}$. The rigid floodplain was made of galvanized steel plate and glued down onto the flume bottom. A thin layer of the $0.8 \mathrm{~mm}$ sand was glued to the floodplain and bank side slope. 

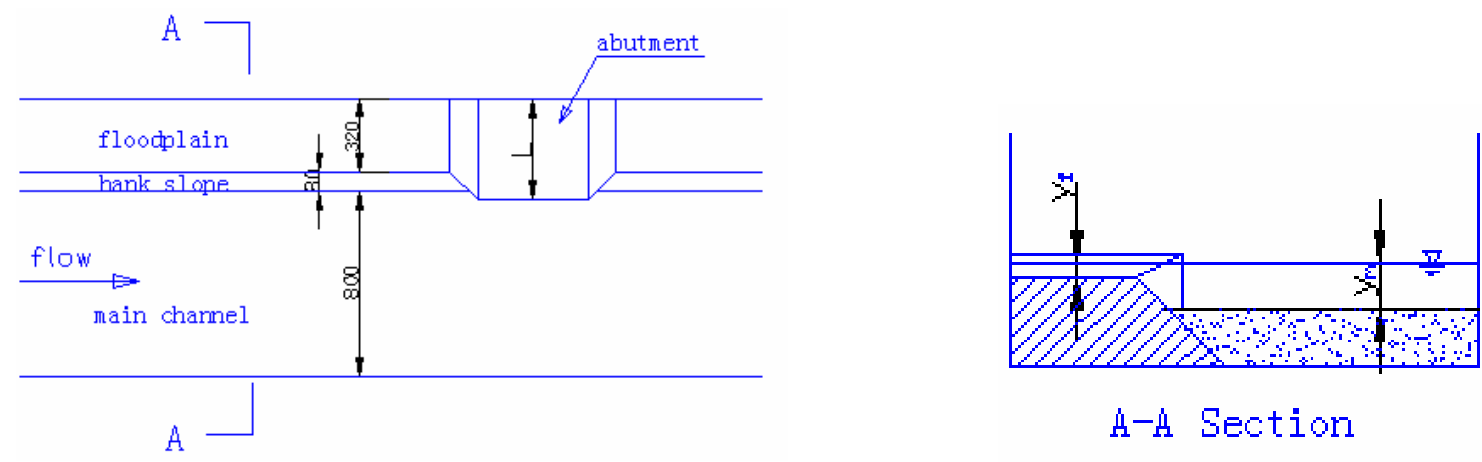

A-H Section

Figure 1: Dimension Sketch for Experimental Compound Channel (mm).

The wing-wall abutment model was made of steel. The dimensions of the model are shown in Figure 2 . The abutment terminated on the bank slope of the main channel as illustrated in Figure1, which corresponds to the type III abutment of Melville (1992). The height between the top of the floodplain and the top of the abutment was $60 \mathrm{~mm}$.

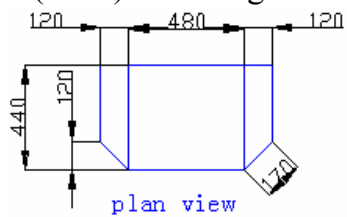

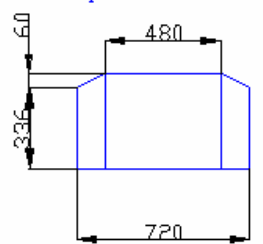

side view

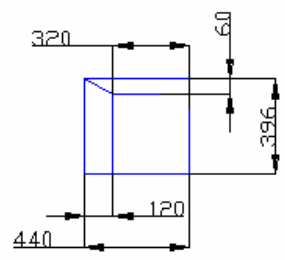

side view
Figure 2: Dimensions of Abutment Model (mm).

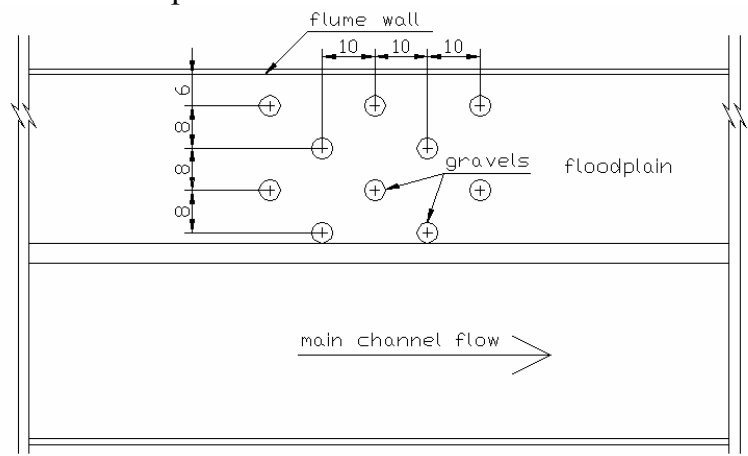

Figure 3: Scheme of staggered placement of gravel on floodplain to provide roughness. Gravels were placed throughout the floodplain (cm).

The bed material used in the experiments had a diameter of $0.8 \mathrm{~mm}$ in both the floodplain and the main channel. The standard deviation of the gradation curve of the material $\sigma_{g}$ is $\sigma_{g}=\left[D_{84} / D_{16}\right]^{1 / 2}=1.37$. According to Shields diagram, the critical shear velocity of the bed sediment is $1.995 \mathrm{~cm} / \mathrm{s}$. The steel floodplain was first primed and painted and then the same size sands of median diameter $0.8 \mathrm{~mm}$ were sprinkled onto the surface of it to provide roughness. The floodplain was further roughened using gravel rocks of average diameter of $4.5 \mathrm{~cm}$ that were placed in a staggered arrangement on the floodplain (Figure 3).

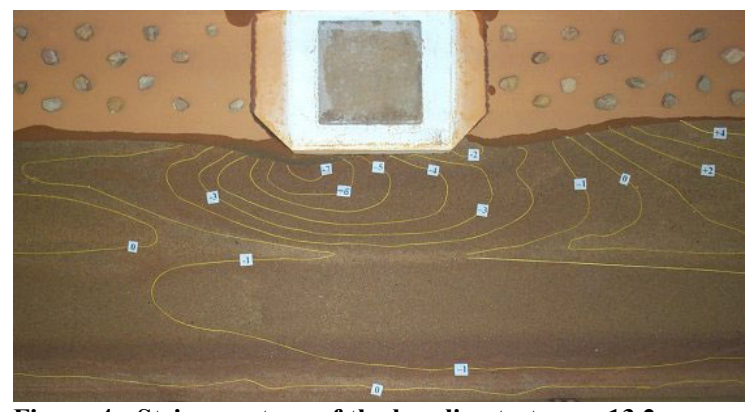

Figure 4: String contour of the baseline test, $y_{m}=13.2 \mathrm{~cm}, y_{f}$ $=5.2 \mathrm{~cm}, \mathrm{Q}=\mathbf{0 . 0 4 4 2} \mathrm{m}^{3} / \mathrm{s}$, time $=\mathbf{4 8 0 0}$ minutes. Flow is from left to right with a staggered arrangement of gravel on the floodplain.

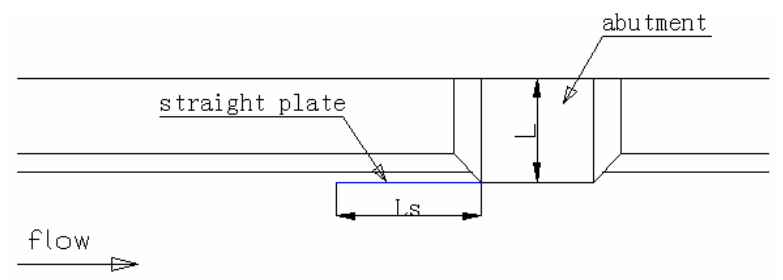

Fig. 5: A sketch of the straight plate cases with varying length $L_{s}$. 


\section{Baseline Experimental Results}

The baseline test was carried out under conditions of $y_{m}=13.2 \mathrm{~cm}, y_{f}=5.2 \mathrm{~cm}$, and $Q=0.0442 \mathrm{~m}^{3} / \mathrm{s}$. From figure 4 it can be seen that the maximum scour, $7.77 \mathrm{~cm}$, took place at the upstream corner of the abutment. This scour depth will be used as the baseline scour depth for abutment scour without any countermeasures.

\section{Solid Parallel Wall Experimental Results}

A series of rectangular straight plates of different lengths, $\mathrm{L}_{\mathrm{s}}$, attached to the upstream end of the abutment parallel to the flow direction were tested (Fig. 5) to assess parallel wall feasibility. Although somewhat impractical to build a solid wall in the field, it could be done in areas where rock is scarce. In these cases, the flow depth on the floodplain, $\mathrm{y}_{\mathrm{f}}$, was equal to $5.2 \mathrm{~cm}$ and the flow depth in the main channel, $\mathrm{y}_{\mathrm{m}}$, was $13.2 \mathrm{~cm}$. The velocity ratio $U / U_{c}$ was about 0.9 in the center of the entire channel. Table 1 gives results of the solid wall experiments.

\begin{tabular}{|c|c|c|c|}
\hline $\begin{array}{l}\text { Straight plate } \\
\text { length (Ls) }\end{array}$ & $\begin{array}{c}\text { Maximum } \\
\text { scour depth at } \\
\text { abutment }(\mathrm{cm})\end{array}$ & $\begin{array}{l}\text { Scour } \\
\text { reduction } \\
\text { rate (\%) }\end{array}$ & $\begin{array}{l}\text { Maximum scour at the } \\
\text { countermeasure }(\mathrm{cm})\end{array}$ \\
\hline $0.3 \mathrm{~L}$, rectangular & 6.25 & 19.6 & 8.65 \\
\hline $0.5 \mathrm{~L}$, rectangular & 4.01 & 48.4 & 8.10 \\
\hline $0.6 \mathrm{~L}$, rectangular & 2.95 & 62.0 & 7.71 \\
\hline $0.7 \mathrm{~L}$, rectangular & 2.15 & 72.3 & 7.83 \\
\hline $0.8 \mathrm{~L}$, rectangular & 1.43 & 81.6 & 7.62 \\
\hline $1 \mathrm{~L}$, rectangular & 0.33 & 95.8 & 7.71 \\
\hline $1.2 \mathrm{~L}$, rectangular & -0.40 & 105.1 & 8.30 \\
\hline $\begin{array}{l}\text { 1L, bank high, } \\
\text { submerged }\end{array}$ & 4.00 & 48.5 & 5.50 \\
\hline $\begin{array}{l}\text { 1.2L, with upstream } \\
0.4 \mathrm{~L} \text { submerged } 4.3 \\
\mathrm{~cm} \text { deep in water }\end{array}$ & 1.74 & 77.6 & 7.80 \\
\hline $\begin{array}{c}\text { Triangular upstream } \\
\text { end }\end{array}$ & 4.63 & 40.4 & 6.83 \\
\hline
\end{tabular}

All the solid parallel walls were seated on the bank slope of the main channel and aligned with the abutment face parallel to the flume wall. The top of each wall was the same height as the top of the abutment except in one case, in which the wall height was $5.2 \mathrm{~cm}$ lower than the flow surface, and also in another case where the wall was partially submerged about $4.3 \mathrm{~cm}$ in the flow. It was found that, in general, walls attached to the upstream end of the abutment were able to move the scour hole upstream from the abutment corner and therefore, was efficient as a scour countermeasure. It was also found that as the length of the wall increased, the scour at the abutment declined. Table 2 shows photographs of the topographic maps of the scoured region after 4800 minutes. 
Table 2: Photographs of selected straight plate tests (flow from left to right, run time $=4800 \mathrm{~min} ., \mathrm{Q}=\mathbf{0 . 0 3 7 9} \pm 0.003 \mathrm{~m}^{3} / \mathrm{s}$ ).

\begin{tabular}{|l|l|}
\hline Parallel wall description & Photographs \\
\hline $\mathbf{L}_{\mathrm{s}}=1.2 \mathrm{~L}, \mathbf{y}_{\mathrm{m}}=13.2 \mathrm{~cm}, \mathbf{y}_{\mathbf{f}}=5.2 \mathrm{~cm}$. \\
$\begin{array}{l}\mathbf{L}=1.0 \mathrm{~L} \text { with the top of the wall } \\
\text { submerged } 5.2 \mathrm{~cm} \text { in the water. } \mathbf{y}_{\mathrm{m}}=\end{array}$
\end{tabular}

\section{Discussion of Plate Length}

Fig. 6 is a plot of the scour depths at the upstream corner of the abutment and the maximum scour depth in the vicinity of the upstream end of the wall versus the length of the wall in terms of the abutment length, $\mathrm{L}_{\mathrm{s}}$. It is seen that as the length of the wall increases from $0.3 \mathrm{~L}$ to $1.2 \mathrm{~L}$, the scour at the abutment decreases rapidly. There is no scour at the abutment corner in 4800 minutes of running when the wall reaches a length of 1.1L. The length of the wall is vital to its success as a countermeasure. If the wall moves the scour hole far enough upstream, the scour hole at the upstream end of the wall will have no impact on the abutment corner and the countermeasure will be considered successful. Otherwise, the abutment corner will still be in the scour region and may be subject to collapse.

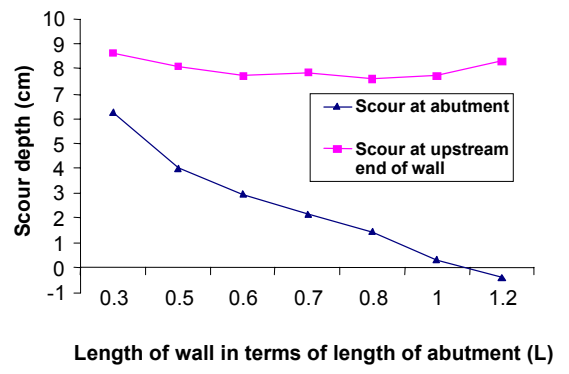

Fig. 6: Scour depth at both abutment and upstream end of wall versus length of wall in terms of wall length. 


\section{Rock Parallel Wall Experimental Results}

A series of rock walls of different lengths $\mathrm{L}_{\mathrm{w}}$ and different protrusion lengths, Lp, were tested (Fig. 7) under clear water conditions. The effect of extending the wall out into the main channel was unclear. Extending the wall could divert flow away from the abutment or it could cause scour-inducing eddies. Rock was thought to be less expensive and easier to construct in the field than a solid wall. These structures are similar to guidebanks without the elliptical upstream end (Bradley, 1978). In these experiments, the flow depth on the floodplain $\left(\mathrm{y}_{\mathrm{f}}\right)$ was equal to $5.2 \mathrm{~cm}$ and the flow depth in the main channel $\left(\mathrm{y}_{\mathrm{m}}\right)$ was $13.2 \mathrm{~cm}$. The velocity ratio $U / U_{c}$ was about 0.9 in the centerline of the entire channel. The top of each wall was the same height as the top of the abutment so that they were not submerged by the flow.
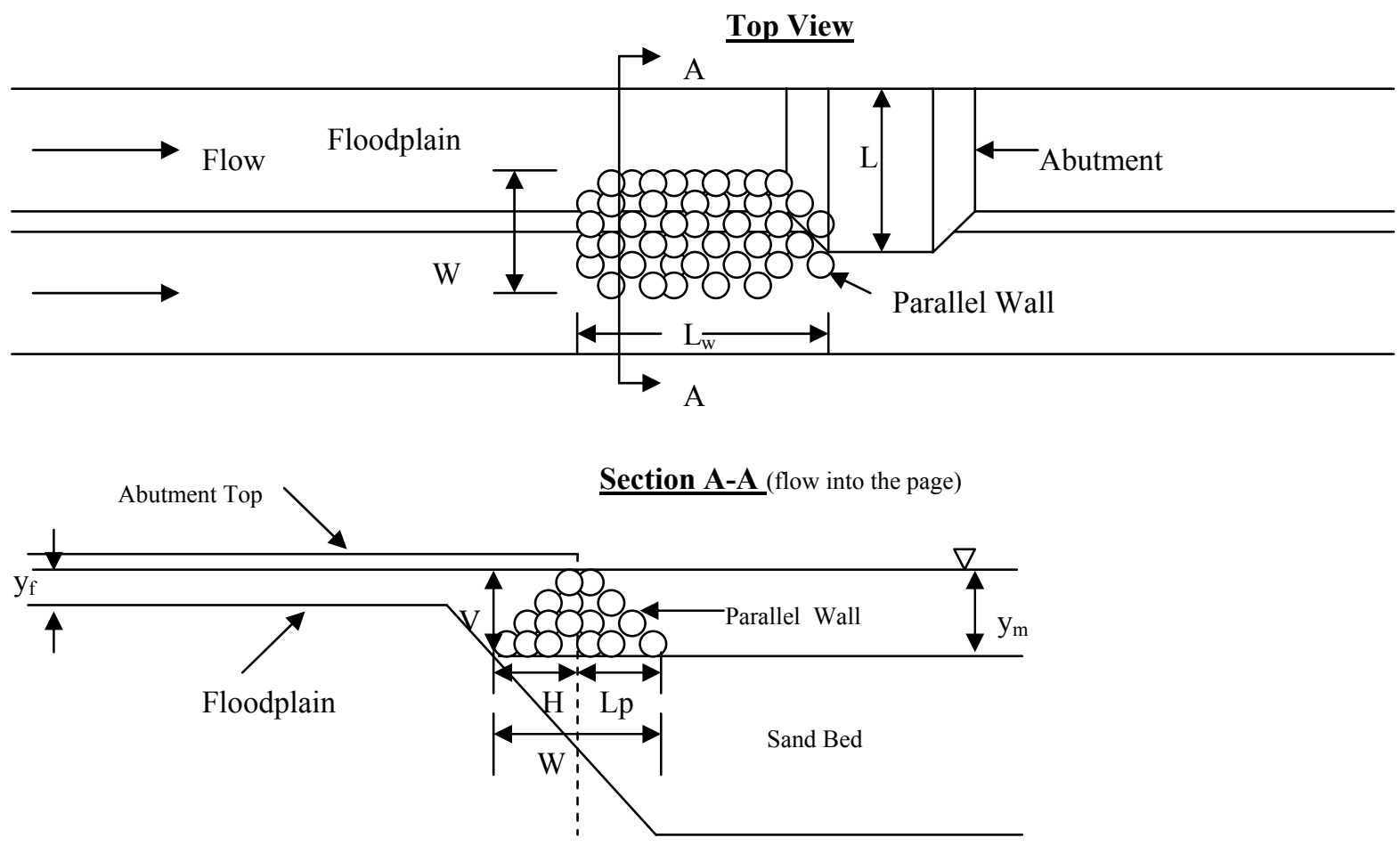

Fig. 7: Definition sketch of parallel wall.

It was found that (a) the walls which were set back onto the floodplain such that the feet of the walls were even with the abutment (no protrusion length, Lp) were very effective in protecting the abutment, (b) those walls whose feet protruded into the main channel beyond the abutment (protrusion length, Lp, greater than zero) tended to produce significant scour in the bridge crossing and potentially threaten the middle and downstream abutment end, and (c) for zero protrusion length, Lp, the protection efficiency of the walls were not sensitive to the lengths of the wall unless the wall was extremely short, for instance, $0.25 \mathrm{~L}$, then the protection efficiency would drop significantly. Overall, the straight wall is an efficient and practical countermeasure to prevent scour at the abutment. 
Table 3: Experimental data of straight stone walls $\left(Q=0.0385 \pm 0.003 \mathrm{~m}^{3} / \mathrm{s}, \mathrm{t}=4800 \mathrm{~min}\right.$. $)$.

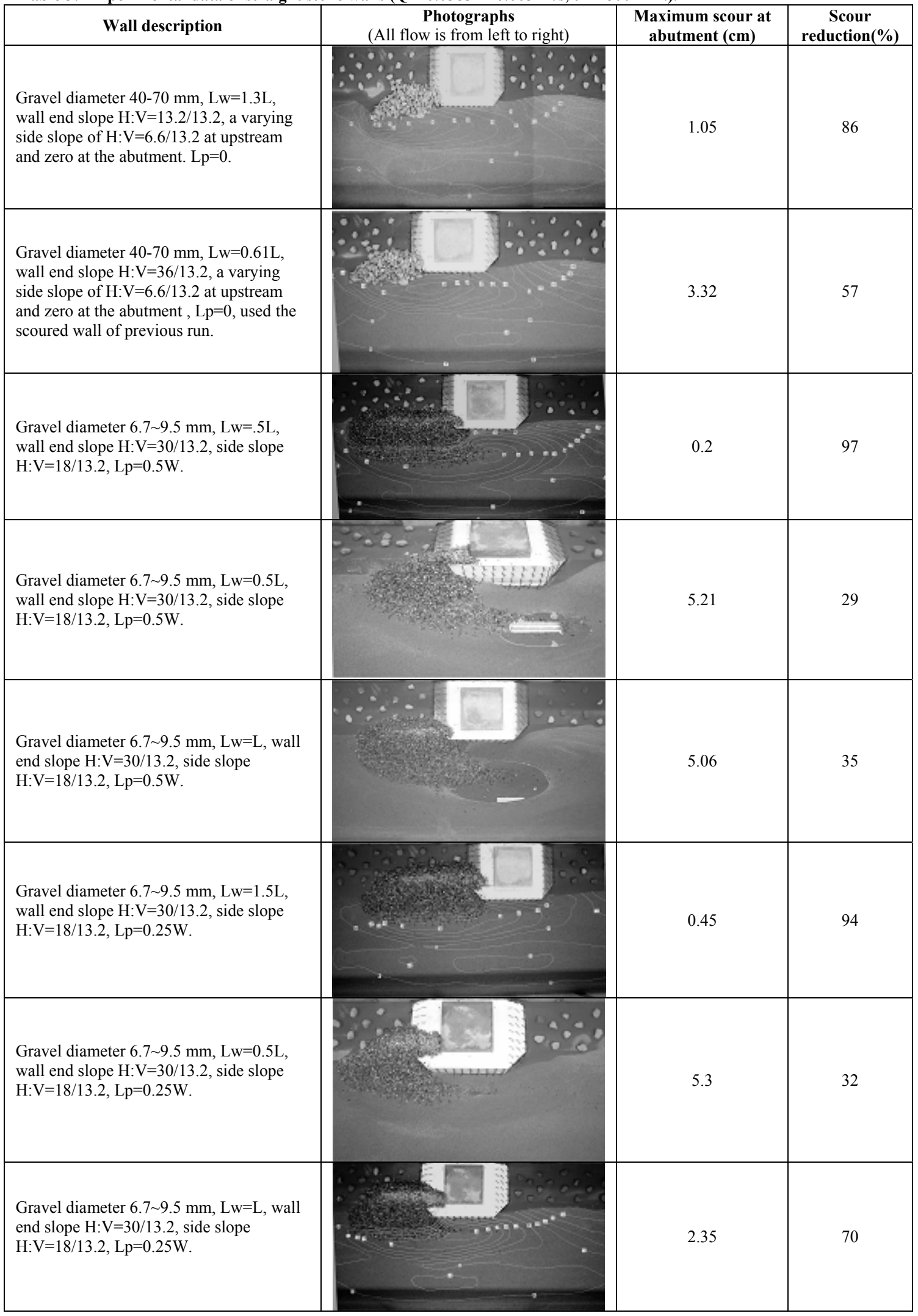




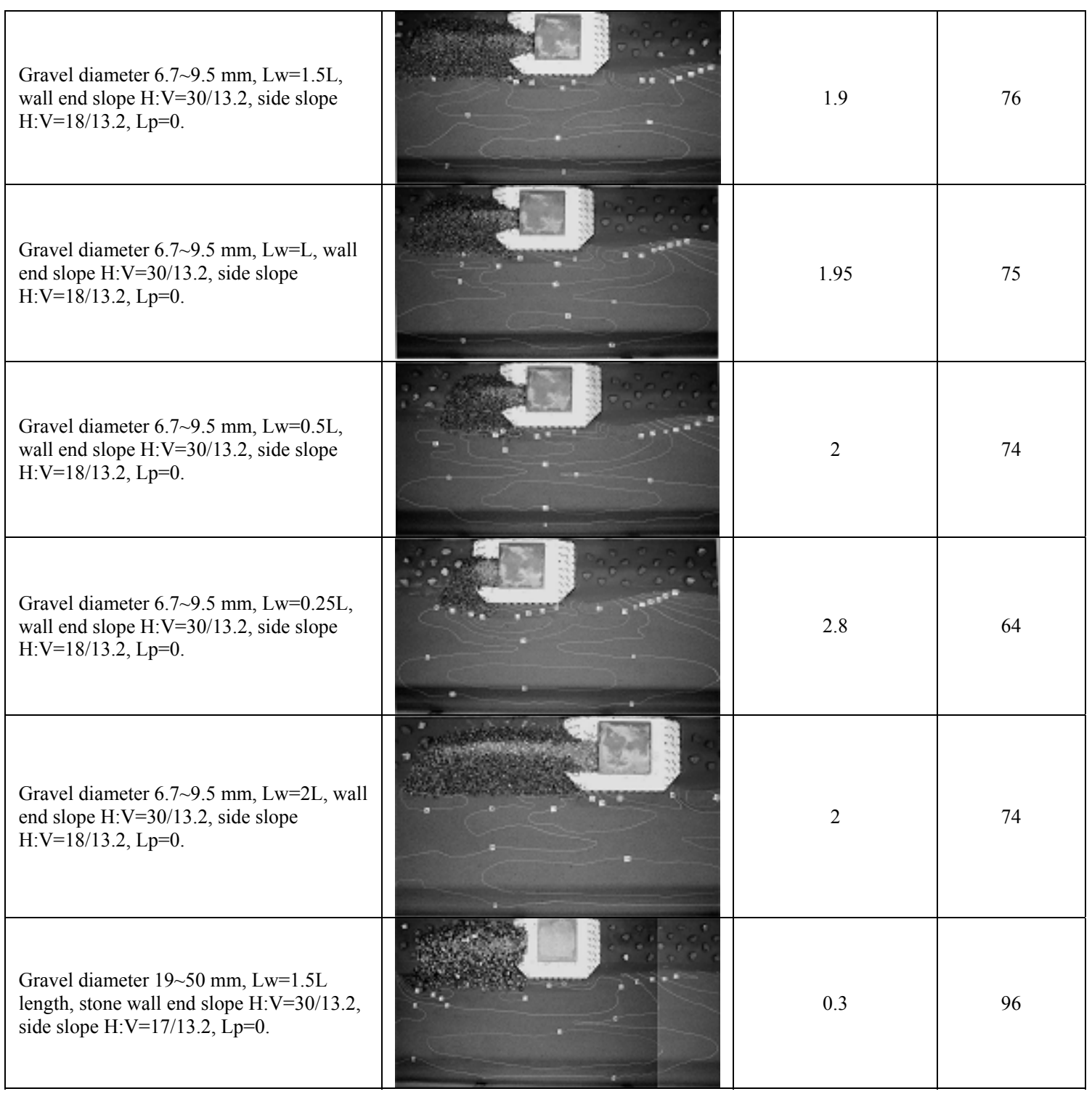

\section{Discussion of Stone Wall Length}

The length of the rock wall is a very important parameter that may affect the efficiency and cost of the stone wall as a countermeasure of abutment scour. Fig. 8 is a plot of scour depth at bridge abutment versus stone wall length for different wall protrusion lengths. It can be seen from the plot that for protrusion lengths $\mathrm{Lp}$, of $0.25 \mathrm{~W}$ and $0.5 \mathrm{~W}$, increases of wall lengths can reduce scour at the abutment significantly. However, for the case of no protrusion, increases of wall lengths do not show obvious effects in reducing scour at the abutment except when the wall is extremely short.

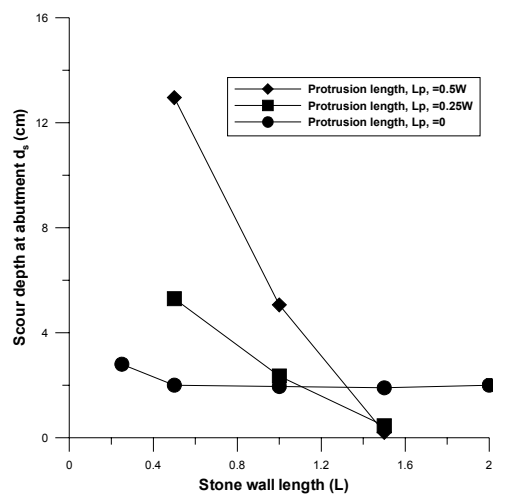

Fig. 8: Plot of scour depth at bridge abutment versus rock wall length for different wall protrusion length. 
Fig. 9 is a plot of the maximum scour depth caused by the wall in the channel versus rock wall length for different wall protrusion lengths. It is seen from this plot that for the $0.25 \mathrm{~W}$ and $0.5 \mathrm{~W}$ protrusion lengths, increases in wall lengths can significantly reduce the maximum scour depth that is induced by the presence of the walls. While for walls with protrusion length of zero, increases in wall length result in essentially no reduction in scour depth when wall lengths are greater than $0.5 \mathrm{~L}$.

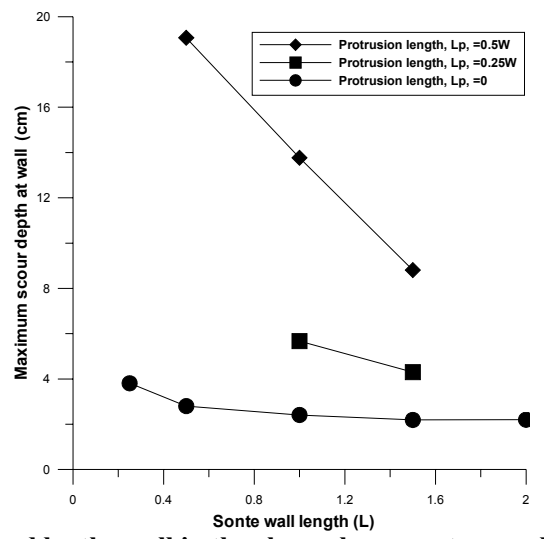

Fig. 9: Plot of the maximum scour depth caused by the wall in the channel versus stone wall length for different wall protrusion lengths.

From the analysis above it can be concluded that for walls with $0.25 \mathrm{~W}$ and $0.5 \mathrm{~W}$ protrusion lengths, increasing wall length increases the level of protection and walls of 1.5 2L length provide the maximum scour reduction. For those walls with no protrusion, since the increase in wall length does not significantly improve the scour reduction rate, therefore it is recommended that $0.5 \mathrm{~L}$ is the optimum length to protect the abutment.

\section{Conclusions}

1. A solid parallel wall attached at the upstream corner of the abutment parallel with the flow can be used as a countermeasure against abutment scour. The length of the solid wall should be $1.1 \mathrm{~L}$ for minimum scour at the abutment.

2. Parallel rock walls attached at the upstream of the abutment can also be used as countermeasures against scour at the abutment. The foot of the wall should not protrude into the main channel beyond the abutment and a wall length of $0.5 \mathrm{~L}$ will provide the sufficient protection at the lowest cost.

\section{Acknowledgement}

This research was conducted under NCHRP 24-18A. Special thanks to Mr. John Cox who helped a great deal in setting up the flume and in operating the measuring instruments.

\section{References}

Bradley, J.N. (1978) "Hydraulics of Bridge Waterways", Hydraulic Design Series No. 1, U.S. Dept. Transportation, Federal Highway Administration, $2^{\text {nd }}$ Ed., Washington, D.C.

Lagasse P. F., Richardson E. V., and. Zevenbergen L. W. (1999). "Design of Guide Banks for Bridge Abutment Protection”. Stream Stability and Scour at Highway Bridges. Reston, VA: ASCE, 0-7844-0407-0, pg. 856.

Lagasse, P. F., Zevenbergen, L. W., Schall, J. D., Clopper, P. E. (2001). Bridge Scour and Stream Instability Countermeasures. Publication No. FHWA NHI 01-003, Hydraulic Engineering Circular No. 23, U. S. Department of Transportation, Federal Highway Administration. Pages 2.7, 2.9, 4.6, 6.16 - 6.18, Design Guidelines 1, 9, 10.

Melville, B.W. (1992). "Local Scour at Bridge Abutments" ASCE Journal of Hydraulic Engineering, Vol. 118, No. 4, April, 1992.

Richardson, E.V. and Simons, D.B. (1984). "Use of spurs and guide banks for highway crossing: Proc. Transportation Research Record 2nd Bridge Engrg. Conf. v2 p.184.

Spring, F.J.E. (1903) "River training and control of the guide bank system," Technical Paper No. 153, Railway Board, Government of India, New Delhi. 